\title{
Neotectonic activity and parity in movements of Udaipur block of the Arvalli Craton and Indian Plate
}

\author{
Harsh Bhu ${ }^{1, *}$, Ritesh Purohit ${ }^{2}$, Joga Ram ${ }^{2}$, Pankaj Sharma ${ }^{2}$ and S R Jakhar ${ }^{3}$ \\ ${ }^{1}$ Department of Geology, ML Sukhadia University, Udaipur 313 001, India. \\ ${ }^{2}$ Department of Geology, Government College, Sirohi 307 001, India. \\ ${ }^{3}$ Department of Geology, JNV University, Jodhpur 342 001, India. \\ *Corresponding author.e-mail: harsh_bhu2003@yahoo.com
}

We report site motion of a permanent GPS site at Udaipur (udai), Rajasthan on the Udaipur block of Aravalli Craton. The GPS measurements of 2007-2011 suggest that the site moves at a rate of about $49 \mathrm{~mm} /$ year towards northeast. As the site motion is consistent with the predicted plate motion using the estimated euler pole of rotation for the Indian Plate, it implies that there is insignificant internal deformation/strain in the region. Such a deformation is consistent with very low seismic activity in the region. The epicenters of the infrequent low magnitude earthquakes are located on the Precambrian lineaments on the west of Udaipur Block, and on the NW-SE striking younger lineament in the south of the block.

\section{Introduction}

Continental scale convulsions had affected major changes in the post-Cenozoic distribution of land masses on the Earth. In the pre-Cenozoic time, the final collision of two continental lithospheric plates, i.e., the Indian and the Eurasian Plate dominated the tectonics which was ultimately responsible for the Himalayan Orogeny (Gansser 1964; Dewey and Bird 1970; Dewey and Burke 1973; Powell and Conaghan 1973; Le Fort 1975). Global plate motion predicts that approximately $4.0 \mathrm{~cm} / \mathrm{yr}$ of northward directed convergence is taking place between Indian Plate and Eurasian Plate (De Mets et al. 1990, 1994; Paul et al. 2001; Jade et al. 2004; Altamini et al. 2007; Banerjee et al. 2008; Gahalaut et al. 2008), out of which about $2 \mathrm{~cm} /$ year is accommodated within the Himalaya (Molnar and Deng 1984; Armijo et al. 1986; Molnar and Lyon-Caen 1989; Bilham et al. 1997; Jouanne et al. 1999). This suggests that the remaining two-third of the total convergence of the Indian Plate is accommodated further north within the Tibetan plateau and in its extrusion towards east. Collision of the Indian Plate and the Eurasian Plate has resulted in many intracontinental deformations typical of Epiorogenic-tectonism in the Indian Plate (Dewey and Burke 1973; Molnar and Tapponnier 1975, 1978; Tapponnier and Molnar 1976, 1977). However, the magnitude and extents of intraplate deformation are variable in expressions. This is mainly due to the release of strain along major faults which has also resulted in reactivation of pre-existing zones of weakness within stable cratons. Consequently, stable regions have also witnessed intraplate seismicity. The same reason is proposed for the vertical movements in the Aravalli Craton of the Indian Plate (Sen and Sen 1983), which has unique tectonic features in the form of Aravalli Mountain Ranges aligned along major faults. These mountain ranges show development of new sets of vertical and rectilinear fractures

Keywords. Indian Plate; Aravalli Craton; lineaments; epicenters; GPS. 
$\left(\mathrm{N} 35^{\circ} \mathrm{W}-\mathrm{S} 35^{\circ} \mathrm{E}\right.$ and $\left.\mathrm{N} 65^{\circ} \mathrm{E}-\mathrm{S} 65^{\circ} \mathrm{W}\right)$ and/or reactivation of the ancient tectonic grains due to the impacts of the Indian and Eurasian Plate collision (Roy 2006). These regional scale rectilinear fractures developed steep dip or vertical orientation and now represent the major lineaments.

In the present study, we estimate the velocity in the lineament bounded Udaipur Block of the Aravalli Craton through a GPS recording station at Udaipur and compare it with the velocities of other IGS stations on the Indian Plate present on the cratonic part of south India. The purpose of this study is also to corroborate the seismicity with lineaments with special reference to Udaipur Block.

\section{Geotectonics of the Aravalli Craton}

The Aravalli Craton occupies an assemblage of Proterozoic fold belts within a reworked Achaean basement complex. These include the Palaeoproterozoic Aravalli Fold Belt and the Mesoproterozoic Delhi Fold Belt. The fold belts are characterized by resurgent tectonics and demarcated by prominent crustal dislocations, delineated by ductile shear zones (figure 1). The Aravalli Mountain Ranges are characterized by horst type features bounded by steeply dipping faults. In the east, the ranges are bounded by two lineaments; the Chittaurgarh-Machilpur Lineament $(\mathrm{H})$ also called as the Great Boundary Fault (GBF) and the Chambal-Jamnagar Lineament $(\mathrm{G})$. On the west, the ranges are bounded by the Luni-Sukri Lineament (J) also called as West Margin Fault (WMF) striking NE-SW and is parallel to the Aravalli Ranges. A prominent thrust zone, the Kaliguman Lineament Zone (KLZ, C) is present, which separates the Delhi Supergroup rocks from the Achaean Sandmata Complex rocks in the north and the Paleoproterozoic Aravalli Supergroup in the south (figure 1). Two prominent NW-SE striking lineaments, i.e., Jaisalmer-Barwani Lineament (L); and BundiKhatu-Sakhi Lineament (M) bound the southern Aravalli ranges around Udaipur (N24 $34^{\prime} 48^{\prime \prime}$ : E73 $\left.42^{\prime} 46^{\prime \prime}\right)$. In the north of Udaipur, the Aravalli Fold Belt is also bifurcated by a prominent dislocation zone called the Banas Dislocation Zone (BDZ). The BDZ represents a deep crustal feature and has been imaged as a west dipping prominent reflection zone by deep seismic reflection profiling in Jahazpur section (Reddy et al. 1995). Another tectonic feature of the Aravalli Fold Belt is the Rakhabdev Lineament (RD) which traverses the older and younger sequences of the Aravalli Supergroup and Deccan Traps in southwest, indicating its reactivation during the Precambrian and Caenozoic (Bakliwal and
Ramasamy 1987). Barkhatia and Gupta (1983) on the basis of satellite imageries suggest that RD lineament is a younger feature.

Large parts of the Aravalli-Delhi mobile belts have subsequently been turned into a tectonically stable block by the Neoproterozoic barring a few lineament zones, which are reported to be active. Some of the Aravalli basins were proposed to have evolved as inverted basin margins (peribasinal) faults (Verma and Grieling 1995) while origin of a few was related with Phanerozoic tectonics (Roy 1988). The Neogene and Quaternary tectonics led to rejuvenation of the old basement faults in the Precambrian crust in NE Rajasthan and segmented blocks of crust were uplifted along faults (Dassarma 1988). The block uplift of the Aravalli/Delhi Proterozoic trend led to decline of elevation near Udaipur (Heron 1953). Sen and Sen (1983) attributed post-Neogene tectonics in the central Aravalli mountain ranges to rejuvenation of regional Precambrian faults, in response to flexural bending of the Indian Plate. The neotectonic activity is also represented by development of gravity high of 80 mgal caused by mobility of mantle material caused by Aravalli uplift (Quereshi 1964). The main gravity high along the Aravalli Mountain Belt is marked by steep rise $\approx 50$ mgal and has been interpreted as uplifted block.

\section{Methodology}

The GPS data have been used to understand the tectonics and geodynamics of the region. The data for this study are obtained from one continuous GPS station at Udaipur (udai) established in 2007 in the Udaipur Block of the Arvalli Craton. The GPS data over a significantly long time span from a permanent station improves the spatial and temporal resolution of the crustal deformation in a study area (Serpelloni et al. 2002, 2005). The permanent station is equipped with a Zypher geodetic grade antenna mounted on a reinforced concrete pillar grouted to a bedrock and the data are recorded on Trimble Net RS GPS receiver. The measurements at this station were made continuously on 24 hour/day/year basis. The data analysed for the study are for the first 10 days of each month. In this prespective, we developed automatic facilities to handle the permanent station data archiving and data processing procedures. We used continuous GPS measurement spanning from 2007-2011 to study the kinematics in the Udaipur Block of the Aravalli Craton. These measurements were also used to determine the baseline lengths between Udaipur-Bangalore (IISc) and UdaipurHyderabad (Hyde) station lines. We also estimated the relative movements of the Bangalore (IISc) 


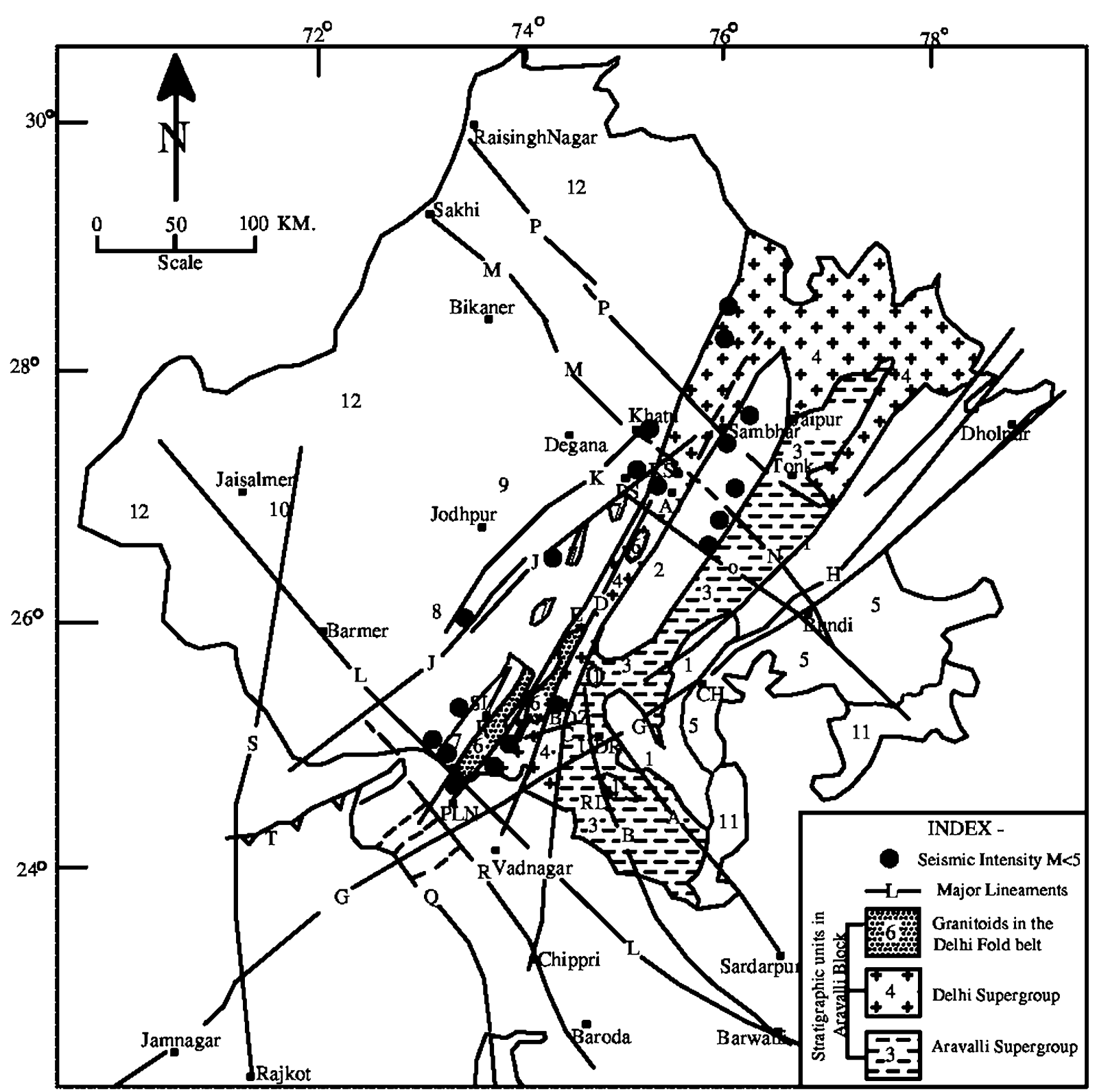

Figure 1. Geological map of Rajasthan with stratigraphic boundaries, major lineaments of Rajasthan and epicenters of earthquakes (modified after Bakliwal and Ramasamy 1987). Major stratigraphic units: (1) Mewar Gneiss Complex, (2) Tectonothermally reworked basement, (3) Aravalli Supergroup, (4) Delhi Supergroup, (5) Vindhyan Supergroup, (6) Granitoid in the Delhi Fold Belt, (7) Sirohi Group, (8) Malani Group, (9) Marwar Supergroup, (10) Mesozoic-Cenozoic, (11) Deccan Trap and (12) Quaternary and Recent. Major lineaments: (1) Udaipur-Sardarpur (A), (2) Rishabdev-Barwani (B), (3) Kishangangarh-Chipri (C), (4) Palanpur-Ranakpur-Phulad-Pishangan (D), (5) Pisangan-Vadnagar and Sadri-Palanpur (E), (6) Sirohi (F). Lineament trends from east to west: (1) Chambal-Jamnagar (G), (2) Chittaurgarh-Machilpur (H), (3) Mount Abu-Bharatpur (I), (4) Luni-Sukri (J), (5) Mokalsar-Degana Lineament (K). Lineament trends from northwestsoutheast: (1) Jaisalmer-Barwani (L), (2) Bundi-Khatu-Sakhi (M), (3) Sakhi-Khatu (Kishangarh-Bundi Lineament in the east) (N), (4) Ajmer-Sadia (O), (5) Raisinghnagar-Tonk (P), (6) West Margin Cambay basin fault (Q), (7) East Margin Cambay basin fault (R). Locations: AJ - Ajmer, CH - Chittaurgarh, KS - Kishangarh, PLN - Palanpur, PS - Pisanganj, RD - Rakhabdev, SI - Sirohi, UDR - Udaipur, BDZ - Banas Dislocation Zone.

and Hyderabad (Hyde) with that of the Udaipur Block in the Aravalli Craton.

The GPS data collected at this site were checked for quality using the TEQC (translation, editing and quality) check software (Estey and Meertens 1999) and analysed along with IGS station data listed in table 1. Daily position of all the sites along with atmospheric, orbital and earth orientation parameters were estimated using the GAMIT/GLOBK software developed by the Massachusetts Institute of Technology (MIT), USA (King and Bock 2006). 
Table 1. Estimated velocity at various GPS sites in ITRF-2008 framework.

\begin{tabular}{|c|c|c|c|c|c|c|}
\hline Site & Lat.(deg.) & Long.(deg.) & $\begin{array}{c}\text { Eastward motion } \\
(\mathrm{mm} / \mathrm{yr})\end{array}$ & $\begin{array}{l}\text { Northward motion } \\
\qquad(\mathrm{mm} / \mathrm{yr})\end{array}$ & $\begin{array}{c}\mathrm{E} \pm \\
(\mathrm{mm} / \mathrm{yr})\end{array}$ & $\mathrm{N} \pm$ \\
\hline Udai & 24.580 & 73.713 & 36.46 & 33.15 & 0.13 & 0.12 \\
\hline Hyde & 17.417 & 78.551 & 40.50 & 34.62 & 0.10 & 0.08 \\
\hline Iisc & 13.021 & 77.570 & 41.92 & 34.75 & 0.12 & 0.10 \\
\hline Coco & -12.188 & 96.834 & 44.66 & 51.64 & 0.12 & 0.10 \\
\hline Sele & 43.179 & 77.017 & 29.61 & 3.42 & 0.08 & 0.09 \\
\hline Karr & -20.981 & 117.097 & 39.05 & 59.09 & 0.11 & 0.10 \\
\hline Wuhn & 30.532 & 114.357 & 31.91 & -11.91 & 0.12 & 0.11 \\
\hline Kunm & 25.030 & 102.797 & 32.10 & -17.98 & 0.12 & 0.11 \\
\hline Pol2 & 42.680 & 74.694 & 26.09 & 4.08 & 0.07 & 0.08 \\
\hline Dgar & -7.270 & 72.370 & 46.23 & 32.90 & 0.13 & 0.13 \\
\hline Kit3 & 39.135 & 66.885 & 29.52 & 4.96 & 0.12 & 0.12 \\
\hline
\end{tabular}

Daily position estimates from GAMIT analysis with covariance matrices were combined using GLOBK by constraining the IGS sites to their ITRF 2008 positions and associated uncertainties to obtain the time series for the cordinate of permanent station. Analysis of the positions in time series for the permanent station observed for last three years provided station velocities, together with the amplitude of the annual and semi-annual signals and the offsets observed in the series. The time series is used to compute horizontal and vertical velocities.

A self-consistent three dimensional velocity field was used for geodynamic and geokinematic applications. The method used is based on a 'distributed session'. It allows for the determination of a self consistent set of station velocities in a uniform reference frame. The velocities of all permanent stations are estimated in the ITFR 2008 reference frame (Altamini et al. 2007) by stabilising IGS station.

\section{Results}

The main outcome of our analysis from a permanent station Udaipur (udai) set on the Udaipur Block are a set of three dimensional postion time series and the site indicates a northeasterly movement (figure 2). The estimated velocity of udai and other IGS station in the ITRF 2008 framework are listed in table 1 . The velocities of the Indian IGS sites and udai are plotted in figure 3 . The velocity of the Udaipur (udai) station obtained from Globk solution is $49.27 \mathrm{~mm} / \mathrm{yr}$ towards $\mathrm{N} 46^{\circ}$, and that of Hyderabad (Hyde) is $53.28 \mathrm{~mm} / \mathrm{yr}$ and Bangalore (IISc) is $54.45 \mathrm{~mm} / \mathrm{yr}$ (table 1 ). Recently Mahesh et al. (2012) have estimated the pole of rotation for the Indian Plate, located at $51.41 \pm 0.07^{\circ} \mathrm{N} ; 8.97 \pm 0.8^{\circ} \mathrm{E}$. These researchers also estimated angular velocity of the pole at $5.539 \pm 0.002^{\circ} / \mathrm{M} / \mathrm{yr}^{-1}$. The pole predicts a velocity of $50.05 \pm 0.1 \mathrm{~mm} /$ year at udai and hence our estimate is consistent with their estimated pole. Other velocity estimates at Hyde and IISc are also consistent with this pole.

\section{Discussions}

A number of researchers in recent years have indicated significant changes in the landforms in the Aravalli and the Vindhyan Craton due to neotectonism. Detailed analysis of lineament features noted in the Indian Shield indicated the sets of WNW-ESE and NE-SW lineament are more persistent pairs of lineaments that developed in Rajasthan and Gujarat. These trends originated later than early-middle Jurassic and have maximum control in the evolution of Quaternary landforms (Roy and Jakhar 2002). Dassarma (1988) listed a number of structural features as evidence of neo-tectonism in the region. Sen and Sen (1983) recognized recent/ post-Neogene geomorphic provinces in central and southern parts of Aravalli Mountains. They presumed flexural bending of the Indian crust as the cause of epeirogenic tectonism observed in the Aravalli Mountains. Sinha Roy (1986) reported the effect of neotectonic activity along the GBF. According to him the indentation of the Bundelkhand massif as a rigid wedge into the Aravalli orogen during the Neogene caused the rejuvenation of older NE-SW and NW-SE faults and the GBF represented the major dislocation zone.

In the northwestern Indian Shield, a few earthquakes have occurred along the lineaments and faults (figure 1). In the Aravalli Craton the continuity of the ancient lineaments up to neotectonically active lineaments has a significant 
UDAI North Offset $2736238.025 \mathrm{~m}$

$w m e a n(m m)=8083.19 \pm 0.13 \mathrm{nrms}=14.16 \mathrm{wrms}=34.2 \mathrm{~mm} \# 372$

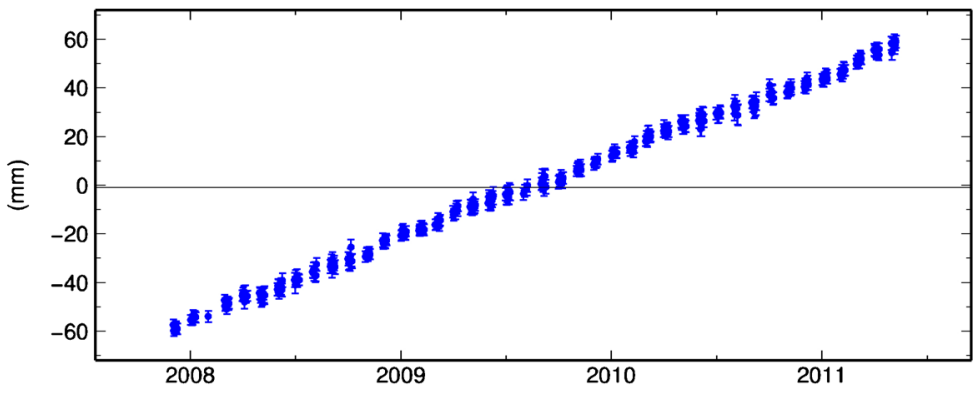

UDAI East Offset $7462108.240 \mathrm{~m}$

wmean $(\mathrm{mm})=8305.29 \pm 0.14 \mathrm{nrms}=14.06 \mathrm{wrms}=37.4 \mathrm{~mm} \# 372$
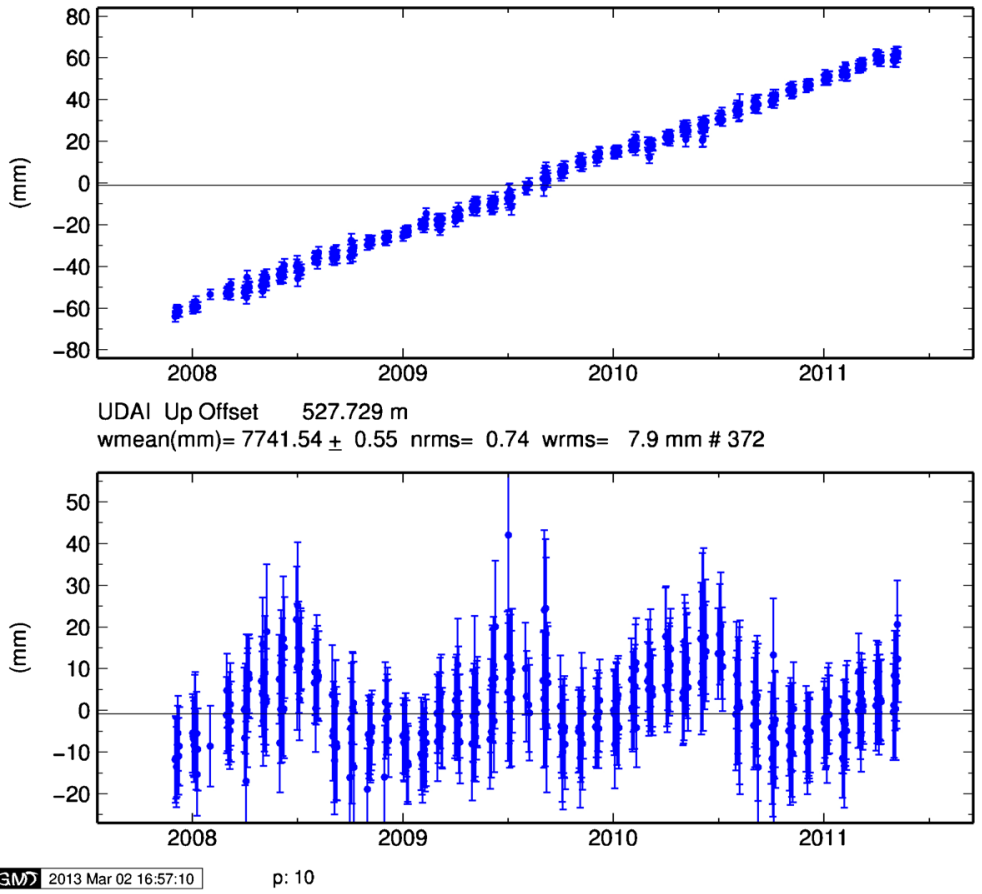

Figure 2. Time series of Udaipur (udai) showing northerly, easterly and upward movements.

Table 2. Earthquake catalogue for Aravalli region, southern Rajasthan and northeast Gujarat (between $23^{\circ}-27^{\circ} \mathrm{N}$ and $\left.73^{\circ}-76^{\circ} \mathrm{E}\right)$.

\begin{tabular}{llcccc}
\hline Year & Month & Date & Lat. (N) & Long. (E) & Mag. (Mw) \\
\hline 1849 & January & 2 & 25.20 & 73.20 & 4.1 \\
1849 & June & 2 & 25.20 & 73.20 & 4.7 \\
1871 & January & 1 & 24.20 & 72.20 & 4.2 \\
1876 & July & 3 & 24.60 & 73.80 & 3.3 \\
1986 & November & 15 & 24.50 & 73.60 & 4.0 \\
1987 & November & 2 & 25.90 & 73.30 & 4.5 \\
1992 & May & 30 & 24.14 & 74.12 & 3.8 \\
2006 & December & 23 & 26.7 & 76.0 & 3.7 \\
2007 & September & 15 & 27.5 & 75.4 & 2.8 \\
2007 & March & 16 & 27.6 & 76.9 & 3.3 \\
2008 & July & 5 & 25.8 & 74.2 & 3.6 \\
2008 & January & 27 & 25.2 & 73.8 & 3.6 \\
\hline
\end{tabular}

www.earthquakeinfo.org (Jaiswal and Sinha 2005). 


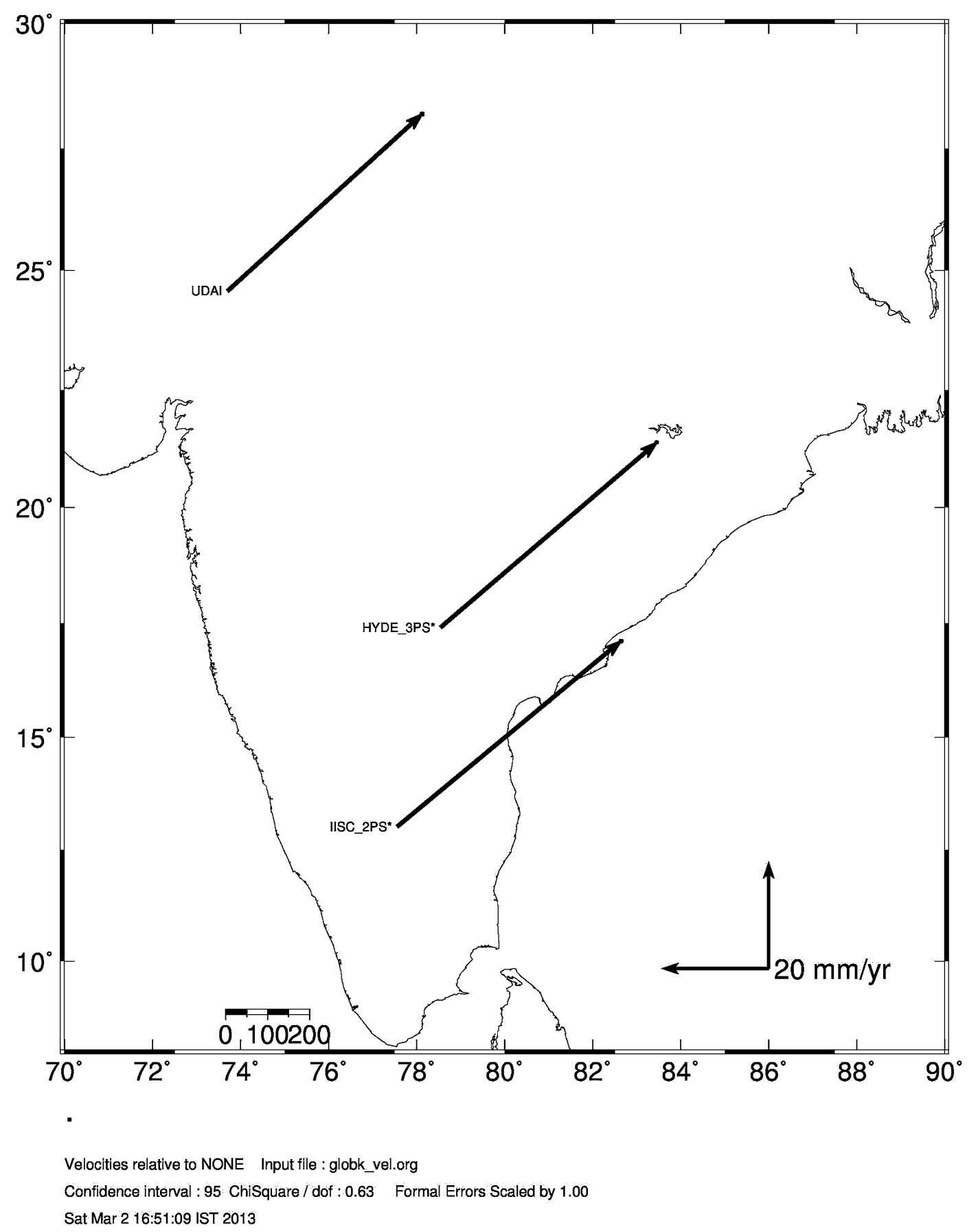

Figure 3. Velocity map for Indian subcontinent.

seismic importance (table 2). The epicenters of these earthquakes are falling on the ancient lineaments represented by tectonic contacts or along the NW-SE striking younger lineaments (figure 1). The epicenters of the earthquakes which are localized on the Precambrian lineaments are on the Palanpur-Ranakpur-Phulad-Pishangan Lineament (D) and Pisangan-Vadnagar Lineament and Sadri-Palanpur Lineament (E) are in the northwest of Udaipur Block only, suggesting the contacts between the remobilized basement and the cover rocks are seismically active. Epicenters are also located on the NW-SE trending lineaments, which are developed due to the Indian Plate collision. The reactivated lineaments bounding the Aravalli Craton suggests intra-plate deformation in the western part of the Indian Plate.

The GPS observation at Udaipur (udai) encompasses the kinematics and geodynamics of the region. This information will certainly benefit the enlargement and improvement of the continuous GPS permanent networks. It may also require a 
multidisciplinary approach through the integration of the seismological, geological and other geophysical and geodetic data. The distributed processing mode adopted in this work allows us to look at the data collected at regional or local scale by GPS permanent networks as well as from a global point of view. It includes local or regional deformations in a plate tectonic framework, with large advantages for a better comprehension of the tectonic and geodynamic processes that are deforming the crust in the Aravalli region.

\section{Conclusions}

The epicenters of the infrequest low magnitude earthquakes along the Udaipur Block are located on the Precambrian lineaments on its northwest, along the contacts of the tectonothermally reworked basement and Aravalli Supergroup along the NW-SE striking younger lineaments. However, the seismicity is very low, implying very small internal deformation. This is confirmed from our GPS measurements at a permanent site at Udaipur. The velocity at this site is about 49.3 $\mathrm{mm} /$ year towards northeast and is consistetnt with the estimated euler pole for the Indian Plate. Thus it is interpreted that the Aravalli Mountain Range behaves as a rigid block with occasional reactivation of the Precambrian Lineaments on the northwestern and northern parts.

\section{Acknowledgements}

The authors are thankful to the Seismology Division of the Ministry of Earth Sciences (MoES) for funding this project (MoES/P./O.(Seismo)/ GPS/46/2005). They are thankful to scientists from GPS Division of ISR, Gandhinagar and NGRI, Hyderabad for their help in processing the data on GAMIT/GLOBK. They are also grateful to SOPAC for making quasi-observation from global networks public available and also providing IGS sites Rinex data, and MIT for the GAMIT/GLOBK software.

\section{References}

Altamini Z et al. 2007 A new release of the international terrestrial reference frame based on time series of station postion and earth orientatiom parameters; J. Geophys. Res. 112B 09401, doi: 10.1029/2007JB004949.

Armijo R, Tapppnnier P, Mercier J L and Tanglin H 1986 Quaternary extension in southern Tibet: Field observation and tectonic implications; J. Geophys. Res. 91 $13,803-13,872$.

Bakliwal P C and Ramasamy S M 1987 Lineament fabric of Rajasthan and Gujarat, India; Records Geol. Surv. India 113(71) 54-64.
Banerjee P, Bürgmann R, Nagarajan B and Apel E 2008 Intraplate deformation of the Indian subcontinent; $\mathrm{Geo-}$ phys. Res. Lett. 35 L18301, doi: 10.1029/2008GL035468.

Barkhatia D K and Gupta R P 1983 Lineament structures in the Precambrian of Rajasthan; In: Structure and Tectonics in the Precambrian rocks of India (ed.) Sinha Roy; Recent Research in Geology (Delhi: Hindustan Publ. Corpn.) 10 186-197.

Bilham R, Larson K, Freymuller J and Project Idylhim Members 1997 GPS measurements of present day convergence across the Nepal Himalaya; Nature 386 61-64.

Dassarma D C 1988 Post-orogenic deformation in the Precambrian crust in northeast Rajasthan; In: Precambrian of the Aravalli Mountain, Rajasthan, India (ed.) Roy A B; Geol. Soc. India Memoir 7 109-120.

De Mets C, Gordon R G, Argus D F and Stein S 1990 Current plate motions; Geophys. J. Int. 101 425-478.

De Mets C, Gordon R G, Argus D F and Stein S 1994 Effect of recent revisions to the geomagnetic time scale on estimates of current plate motions; Geophys. Res. Lett. 21 2191-2194.

Dewey J F and Bird J M 1970 Mountain belts and new global tectonics; J. Geophys. Res. 75 2615-2647.

Dewey J F and Burke K C A 1973 Tibetan, variscan and Precambrian basement reactivation: Product of continental collision; J. Geol. 81(6) 683-692.

Estey L H and Meertens C M 1999 GPS Solution; 342p.

Gahalaut V K, Jade S, Catherine J K, Ananda M B, Kumar P, Narsiah M, Jatri S S H, Ambikapathy A, Bansal A, Chadha R K, Gupta D C, Nagarajan B and Kumar S 2008 GPS measurements of postseismic deformation in the Andaman-Nicobar region following the giant 2004 Sumatra-Andman earthquake; J. Geophys. Res. 113 B08401, doi: 10.1029/2007JB005511.

Gansser A 1964 The Geology of the Himalaya (London: Interscience), 289p.

Heron A M 1953 The geology of central Rajputana; Geol. Surv. India Memoir $\mathbf{7 9}$ 1-389.

Jade S et al. 2004 Preliminary tests of plate-like or continuous deformation in Tibet; Geol. Soc. Am. Bull. 116 1385-1391.

Jaiswal K and Sinha R 2005 www.Earthquakeinfo.org.

Jouanne F, Mugnier M, Pandey J, Gamond P, Le Fort L, Surruier C, Vigny and Avouac J-P 1999 Oblique convergence in the Himalaya of western Nepal deducted from preliminary results; Geophys. Res. Lett. 26 1933-1936.

King R W and Bock Y 2006 Documentation for the GAMIT GPS analysis software; Massachusetts Inst. of Technology, Massachusetts.

Le Fort P 1975 Himalayas: The collide range, present knowledge of the continental arc; Am. J. Sci. 275A 1-44.

Molnar P and Lyon-Caen H 1989 Fault Plane solution of earthquakes and active tectonics of the Tibetan plateau and its margins; Geophys. J. Int. 99 123-153.

Molnar P and Deng Q 1984 Faulting associated with large earthquakes and the average rate of deformation in central and eastern Asia; J. Geophys. Res. 89 6203-6227.

Molnar P and Tapponnier P 1975 Cenozoic tectonics of Asia: Effects of a continental collision; Science 189 419-426.

Molnar P and Tapponnier P 1978 Active tectonics of Tibet; J. Geophys. Res. 83(B-11) 5361-5376.

Mahesh P, Catherine J K, Gahalaut V K, Bhaskar Kundu, Ambikapathy A, Amit Bansal, Premkishore L, Narsaiah M, Sapna Ghavri, Chada R K, Pallabee Choudhary, Singh D K, Singh S K, Subhash Kumar, Nagarjan B, Bhatt B C, Tiwari R P, Arun Kumar, Ashok Singh, Harsh Bhu and Kalita S 2012 Rigid Indian Plate: Constraints from GPS measurements; Gondwana Res. 22 1068-1072. 
Paul J, Burgmann R, Gaur V K, Bilham R, Larson K M, Anand M B, Jade S, Mukal M, Anupama T S, Satyal G and Kumar D 2001 The motion and active deformation in India; Geophys. Res. Lett. 28 647-651.

Powell C M and Conaghan P J 1973 Plate tectonics and the Himalayas; Earth Planet Sci. Lett. 20(1) 1-12.

Quereshi M N 1964 Gravity anomalies as related to regional tectonics of peninsular India; Rep. 22nd Int. Geol. Cong. 4490.

Reddy P R, Prasad B R, Rao V V, Khare P, Rao G K, Murty A S N, Sarkar D, Raju S, Rao G P S and Sridher V 1995 Deep seismic reflection profiling along Nandsi-Kunjer section of Nagaur-Jhalawar transect: Preliminary results; In: Continental crust of NW and central India (eds) Sinha-Roy S and Gupta K R, Geol. Soc. India Memoir $31353-372$.

Roy A B 1988 Stratigraphic and tectonic framework of the Aravalli mountain ranges; In: Precambrian of the Aravalli mountains, Rajasthan, India (ed.) Roy A B, Geol. Soc. India Memoir 7 3-31.

Roy A B 2006 Seismicity in the peninsular Indian shield: Some geological considerations; Curr. Sci. 91(4) 456-463.

Roy A B and Jakhar S R 2002 Geology of Rajasthan (northwest India): Precambrian to Recent; Scientific Publishers, Jodhpur, 421p.
Sen D and Sen S 1983 Post-Neogene along the Aravalli Range, Rajasthan, India; Tectonophys. 93 75-98.

Serepelloni E, Anzidei M, Baldi P, Casula G, Galvani A, Pesci A and Riguzzi F 2002 Combination of permanent and nonpermanent station GPS networks for the evaluations of the strain rate field in the central Mediterranean area; Boll. Geofis. Teor. Appl. 43 195-219.

Serpelloni E, Anzidei M, Baldi P, Casula G and Galwani A 2005 Crustal velocity and strain rate fields in Italy and surrounding regions: New results from the analysis of permanent and nonpermanent GPS networks; Geophys. J. Int. 161(3) 861-880, doi: 10.1111/j.1365-246X.2005.02618.x.

Sinha Roy S 1986 Himalayan collision and indentation of Aravalli orogen by Bundelkhand wedge: Implications for Neotectonics in Rajasthan; Int. Symp. on Neotectonics in South Asia, Dehra Dun, pp. 13-24.

Tapponnier P and Molnar P 1976 Slip plane field theory and large scale continental tectonics; Nature 264 319-324.

Tapponnier P and Molnar P 1977 Active faulting and tectoniocs in China; J. Geophys. Res. 82 2905-2930.

Verma P K and Greiling R O 1995 Tectonic evolution of the Aravalli Orogen (NW India): An inverted Proterozoic rift basin; Geol. Rundsch. 84 683-69. 